\title{
JOB O EL SUFRIMIENTO DEL JUSTO
}

\author{
JOB OR THE SUFFERING OF THE RIGHTEOUS
}

\author{
Diego Pérez-Gondar \\ Universidad de Navarra
}

\begin{abstract}
The question about the meaning of the suffering of the innocent is inescapable. In the biblical tradition, this subject is treated in a particularly profound way in the book of Job. Paradoxically, this book is little known. This article describes the elements that articulate this book according to its complex structure and its poetic peculiarity. That understanding helps to explain the various interpretations and re-readings that this work experienced in Judaism of the pre-Christian period, in the origin of Christianity and in later Rabbinism. Since the central theme is always current, this work helps readers to better read this biblical book and makes them understand its importance and transcendence in the history of Western culture.
\end{abstract}

KEYWORDS: Job; Suffering; Pain; Meaning; Rereading; Literary Structure.

RESUMEN • La pregunta acerca del sentido del sufrimiento del inocente es ineludible. En la tradición bíblica, este tema es tratado de un modo particularmente profundo en el libro de Job. Paradójicamente, este libro es poco conocido. Este trabajo describe los elementos que articulan este libro atendiendo a su estructura compleja y a su peculiaridad poética. Esa comprensión ayuda a explicar las diversas interpretaciones y relecturas que esta obra experimentó en el judaísmo del período precristiano, en el origen del cristianismo y en el rabinismo posterior. Como el tema central es siempre actual, este trabajo ayuda al lector a leer mejor este libro bíblico y hace comprender su importancia y trascendencia en la historia de la cultura occidental.

PALABRAS CLAVES: Job; Sufrimiento; Dolor; Sentido; Relectura; Estructura literaria. 


\section{INTRODUCCIÓN}

El libro de Job es una obra maestra de la literatura bíblica. Se trata de una obra fascinante y desconcertante a la vez. El texto es largo y complejo y, en muchos momentos, difícil de seguir. Pero la característica más notable podría ser su «inevitabilidad». En efecto, tarde o temprano, toda existencia humana se encuentra con los temas que este libro aborda de un modo atrevido, incluso subversivo. Paradójicamente, el libro de Job es uno de los libros bíblicos menos conocidos y leídos. En general, nos conformamos con el esquema sencillo de su marco narrativo, sin entrar a interactuar con el Job poético, tan actual y provocador. De hecho, el verdadero sentido del libro de Job no se muestra si el lector no se lo toma en serio, y eso requiere de alguna ayuda externa. Prueba del reto que supone profundizar en el sentido de esta expresión de la literatura sapiencial bíblica es la historia de su interpretación. En cada paso, cada intérprete muestra su interés en alguno de los aspectos del libro, dejando otros de lado. Así, debemos esperar a los avances en la crítica literaria reciente, que ponen un adecuado énfasis en el estudio de la estructura de las obras literarias, para captar mejor la riqueza de este libro complejo y para comprender mejor su fuerza expresiva.

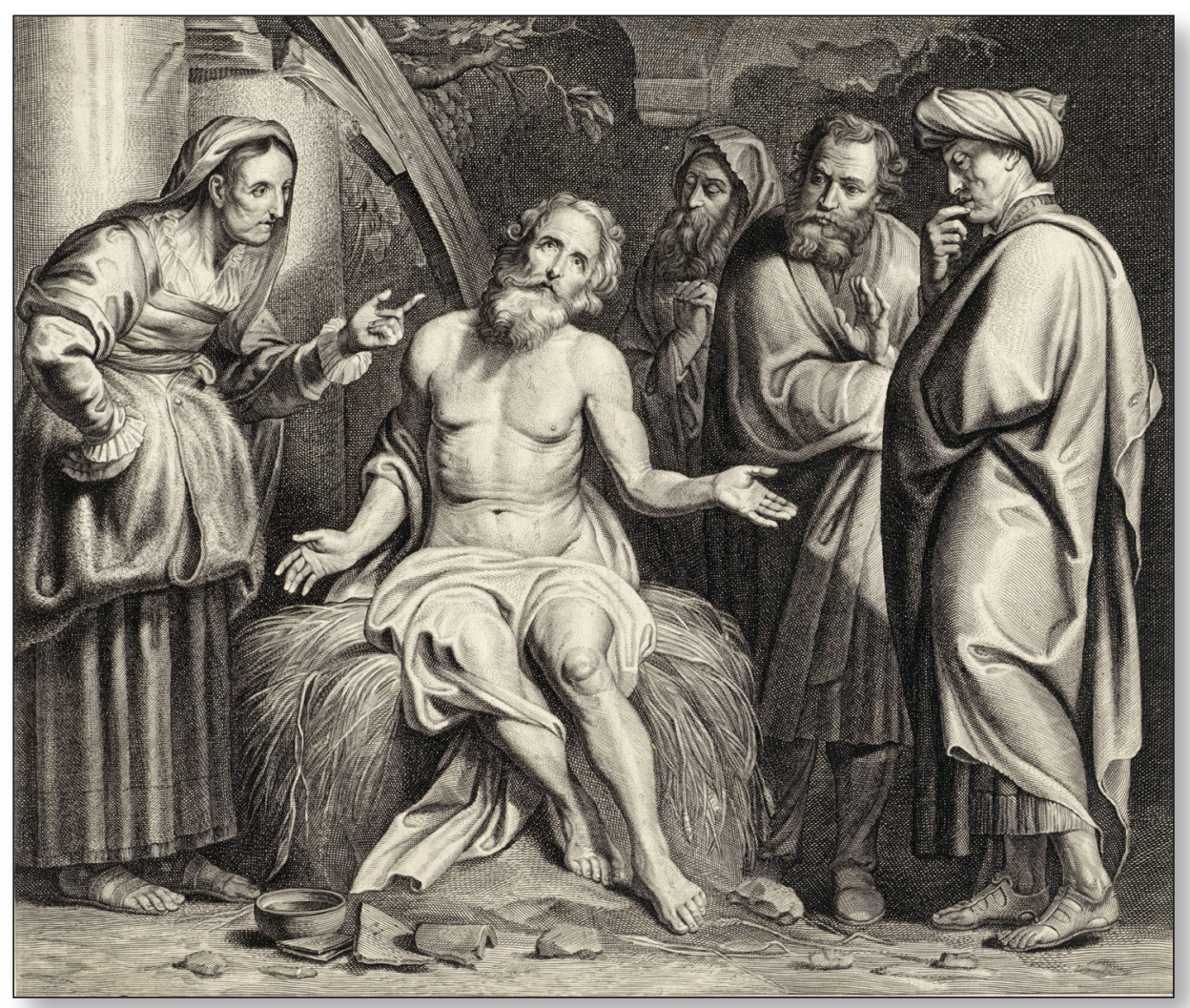

Fig. 1. Grabado de Ciriaco a Tritsum a partir de Gerard Seghers, El paciente Job. Amsterdam, Rijksmuseum, s. XVII. 
Jean Lévêque introducía su explicación del libro de Job justificando su «inevitabilidad»:

Toda lectura sana del libro de Job desemboca en esos problemas primordiales con los que el creyente tiene que vérselas más pronto o más tarde: el misterio del mal y del sufrimiento, el encuentro con Dios hasta en el fracaso aparente de todo éxito humano, las dificultades de dialogar con el hombre que sufre, y finalmente el sentido de la propia vida, cuando se trata de integrar en ella la perspectiva de la muerte (Lévêque, 1987: 5).

A primera vista, el libro de Job plantea una meditación acerca del sufrimiento. Y se interroga acerca del silencio de Dios ante el sufrimiento, especialmente el del inocente. En definitiva, lo que el libro parece tratar es acerca del sentido de la tragedia de la condición humana cuando ésta se manifiesta en toda su crudeza. Pero lo que más puede desconcertar al lector es la ausencia de una respuesta directa y convincente. Eso es así porque la respuesta es misteriosa y requiere de un proceso interior del lector. De lo que trata el libro es del combate de la fe, de cómo son los caminos de Dios en la vida del hombre. Aceptando los aspectos dramáticos que constituyen muchos momentos de esa vida, ¿quién es Dios en verdad? En ese sentido, el libro se podría considerar una teodicea. Desde esa perspectiva, el libro de Job intenta explicar su propuesta acerca de Dios. Como en otros libros sapienciales, el texto ofrece una larga reflexión en la que diversos puntos de vista se van confrontando. Lo más importante es comprender cuál es la propuesta clave, la intentio operis, a través de la estructura y de los elementos significativos que la obra posee.

El libro de Job surgió en un entorno cultural del que toma varios de sus géneros literarios. Además, su temática propia ya había sido abordada, aunque nunca con su profundidad y amplitud, por otras obras sapienciales anteriores. Los comentadores del libro de Job suelen compararlo con otras obras de su entorno y coinciden en afirmar que:

el libro de Job es una cumbre de la literatura universal, muy superior a cualquiera que se le intente comparar. Basta tener en cuenta su enorme extensión comparada con las otras obras, la complejidad de su estructura, el dramatismo mantenido hasta el último momento, la riqueza de la problemática, los motivos totalmente nuevos (como la gran importancia que adquiere la naturaleza y la historia) o el profundo cambio a que son sometidos los antiguos. Quien desee quitar mérito y originalidad al libro de Job sólo conseguirá quedar en ridículo (Alonso y Sicre, 1983:35). ${ }^{1}$

\section{EL LIBRO DE JOB: SU TEXTO HEBREO}

\section{UN JOB DESDOBLADO: EL JOB NARRATIVO Y EL JOB POÉTICO}

El libro de Job tiene cuarenta y dos capítulos. Lo que muchos conocen del libro de Job es un esquema de su corta parte narrativa (Job 1-2;42,7-17). Este cuento tradicional, en parte común a otras culturas del Oriente Medio Antiguo, en el fondo, presenta un marco necesario para la larga reflexión escrita en poesía. Esa amplia sección del libro, poco conocida, no ha dejado una huella profunda en la cultura literaria o artística. La idea de un Job paciente que recibe de Dios el bien y el mal y que no se rebela ante el sufrimiento inmerecido, sí se

1. Para un recorrido por las obras que pueden considerarse precursoras del libro de Job, cf. Alonso y Sicre, 1983: 21 -36. Todas ellas son anteriores a nuestro libro, algunas alrededor de un milenio. Ver también Hartley, 2008: 346-346. Para una introducción y comentario exegético actualizado: Morla, 2017.

IMAGO, NÚM. II, 2019, 2I-40 
hará popular y llegará a representarse en capiteles medievales y será objeto de comentarios edificantes. Un buen ejemplo de ello es uno de los capiteles románicos (s. XII) del claustro de la catedral de Pamplona, expuesto en el museo de Navarra [fig. 2].
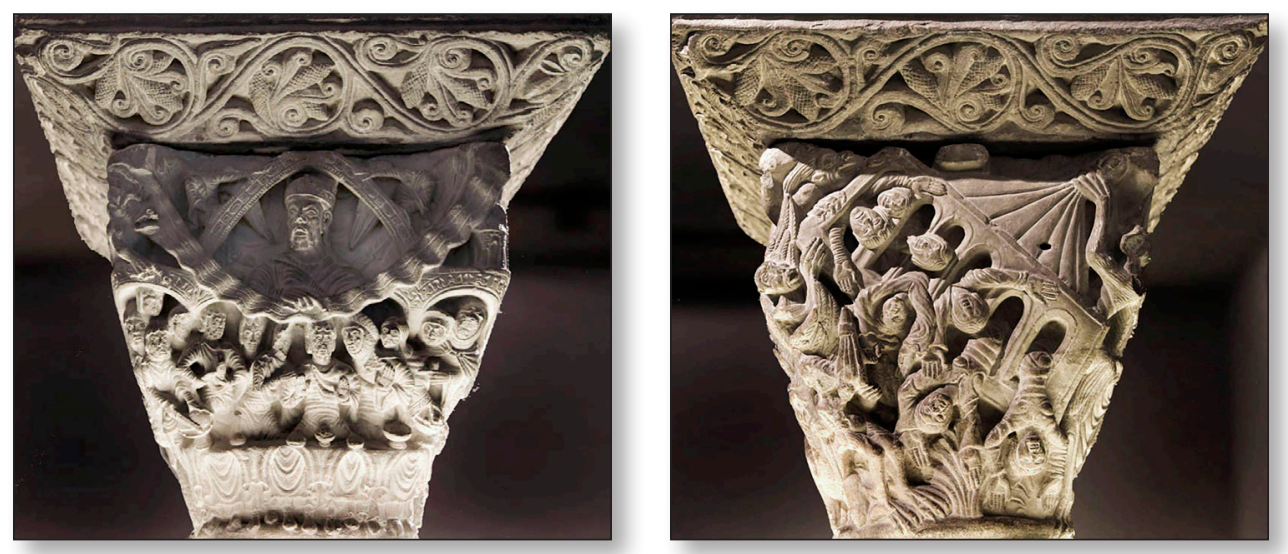

Fig. 2. Dos de las caras de uno de los capiteles del claustro románico de la Catedral de Pamplona, s. XII, Museo de Navarra.

La introducción narrativa del libro cuenta que Job es el mejor de los hombres. La trama va presentando de modo alternativo la escena terrena de Job y la escena celeste en la que Dios presume de Job, pues no hay nadie como él en la tierra. Después de sufrir la pérdida de sus bienes y de sus hijos, Job "se levantó, se rasgó el manto, se rapó la cabeza, se echó por tierra y dijo: “Desnudo salí del vientre de mi madre y desnudo volveré a él. El Señor me lo dio, el Señor me lo quitó; bendito sea el nombre del Señor". A pesar de todo esto, Job no pecó ni protestó contra Dios» (Job 1,20-22). Después de caer enfermo y en pleno sufrimiento, cuando su mujer le incita a blasfemar y a rechazar a Dios, Job replica: «Hablas como una necia. Si aceptamos de Dios los bienes, ¿no vamos a aceptar los males?», y el narrador añade: "A pesar de todo, Job no pecó con sus labios» (Job 2,10).

El Job de la sección poética, que habla lleno de llagas supurantes defendiendo su inocencia, es quizás menos conocido. Muchos desconocen este amplio y dramático paréntesis antes del final feliz del epílogo. Lo que más gusta al lector es que la cosa acaba bien al final. $\mathrm{Y}$, de hecho, sin ese marco, sería muy difícil soportar algunas de las cosas que Job dice en sus monólogos o en las respuestas a las intervenciones de sus amigos.

\section{LAS SECCIONES DE LIBRO DE JOB}

Para facilitar la descripción presentamos las principales secciones de las que consta el libro y su posible fecha de composición. ${ }^{2}$ Aunque el libro tal como lo tenemos se considera del s. IV-III a.C., algunas de sus secciones son muy anteriores:

- Cuento primitivo breve.

2. Para una visión de conjunto de la estructura del libro y de su función significativa puede consultarse Walton: 333-346. 
- Sección narrativa: Job 1-2;42,7-17 (¿s. X-IX?).

- Sección poética compleja y larga:

a) Diálogos con sus amigos Elifaz, Bildad y Sofar (Job 4-27) y monólogos de Job (Job 3;29-31) (primera mitad s. V a.C.).

b) Las dos Teofanías (Job 38,1-42,6) (s. V a.C.).

c) Discursos de Elihú (Job 32-37) (ca. 450 a.C.).

d) Himno sobre la Sabiduría inalcanzable (Job 28) (s. IV-III a.C.).

\section{EL CUENTO TRADICIONAL, MARCO DE TODO EL LIBRO}

En las escenas terrestres de la sección narrativa y en la parte poética, Job desconoce absolutamente qué ha acontecido en la esfera celeste. Job no sabe que Dios le tiene por el mejor de los hombres. Dios no es quien causa directamente sus males. El personaje clave es «el satán", un personaje angélico que no debemos confundir con Satanás, el ángel caído de las concepciones posteriores. El texto hebreo no muestra un nombre propio y añade un artículo al término "satán». Debemos situarnos en un estadio primitivo de la angelología bíblica, cercano aún a las influencias que los hebreos recibieron al contactar con las civilizaciones orientales. Por ese motivo, la figura de un «tentador o acusador», que forma parte de la corte divina, es algo común y que aparece en otras secciones de la Biblia (cf. Za 3,1). Esa concepción será superada en la apocalíptica posterior. ${ }^{3}$ Lo que interesa resaltar aquí es que esta posición ambigua de "el satán" (enemigo del hombre, pero no de Dios) sirve al compositor del libro de Job para exculpar a Dios de la responsabilidad directa de los males que sufre Job. Ahora bien, después de la aparición de este personaje, "el satán" desaparece por completo en todo el libro. No vuelve a aparecer ni siquiera en el epílogo.

Job desconoce que "el satán" ha sido el instigador de sus males y su ejecutor directo. Job supone que sólo Dios puede ser el responsable y no entiende el porqué. Toda su reflexión se dedica a comprender la razón de sus males, pues él es justo e inocente ante Dios. Lo que desea es que Dios hable y calme su sed de sentido.

En esta parte inicial del libro de Job, lo que está en juego es una crítica directa a una moral basada en el do ut des. Esta forma de pensar estaba muy extendida y generalizada. El autor plantea su objeción mediante la pregunta inicial de la parte narrativa y que «el acusador» dirige a Dios: ¿Es Job justo de verdad o por los beneficios que esto le produce? «Satán contestó al Señor: «¿Y crees que Job teme a Dios de balde? ¿No has levantado tú mismo una valla en torno a él, su hogar y todo lo suyo? Has bendecido sus trabajos, y sus rebaños se extienden por el país. Extiende tu mano y daña sus bienes y iya verás cómo te maldice en la cara!»» (Job 1,9-11). La respuesta de Dios es que Job es justo por encima de todo. Para demostrarlo, Dios permite que Satán pruebe la sinceridad de Job a través de las pruebas de todos conocidas.

El lector sabe que Job ignora la escena celeste del relato. Por eso percibe la situación angustiosa de Job, pero, al mismo tiempo, le ayuda a mantener el suspense acerca del desarrollo de la obra: sabe más que Job y eso le ayuda a comprender su posición, y a captar mejor lo que el libro quiere transmitir. Esto constituye un sofisticado elemento estructural que le permite aceptar las expresiones duras que Job expresa en determinados momentos de sus monólogos o diálogos con sus amigos Elifaz, Bildad y Sofar.

3. En el s. III a.C. (por ejemplo, en l Cro 21,1) aparece ya Satán como nombre propio designando a un ser demoníaco superior que se rebela contra Dios. Este personaje es común en toda la literatura intertestamentaria extrabíblica. 


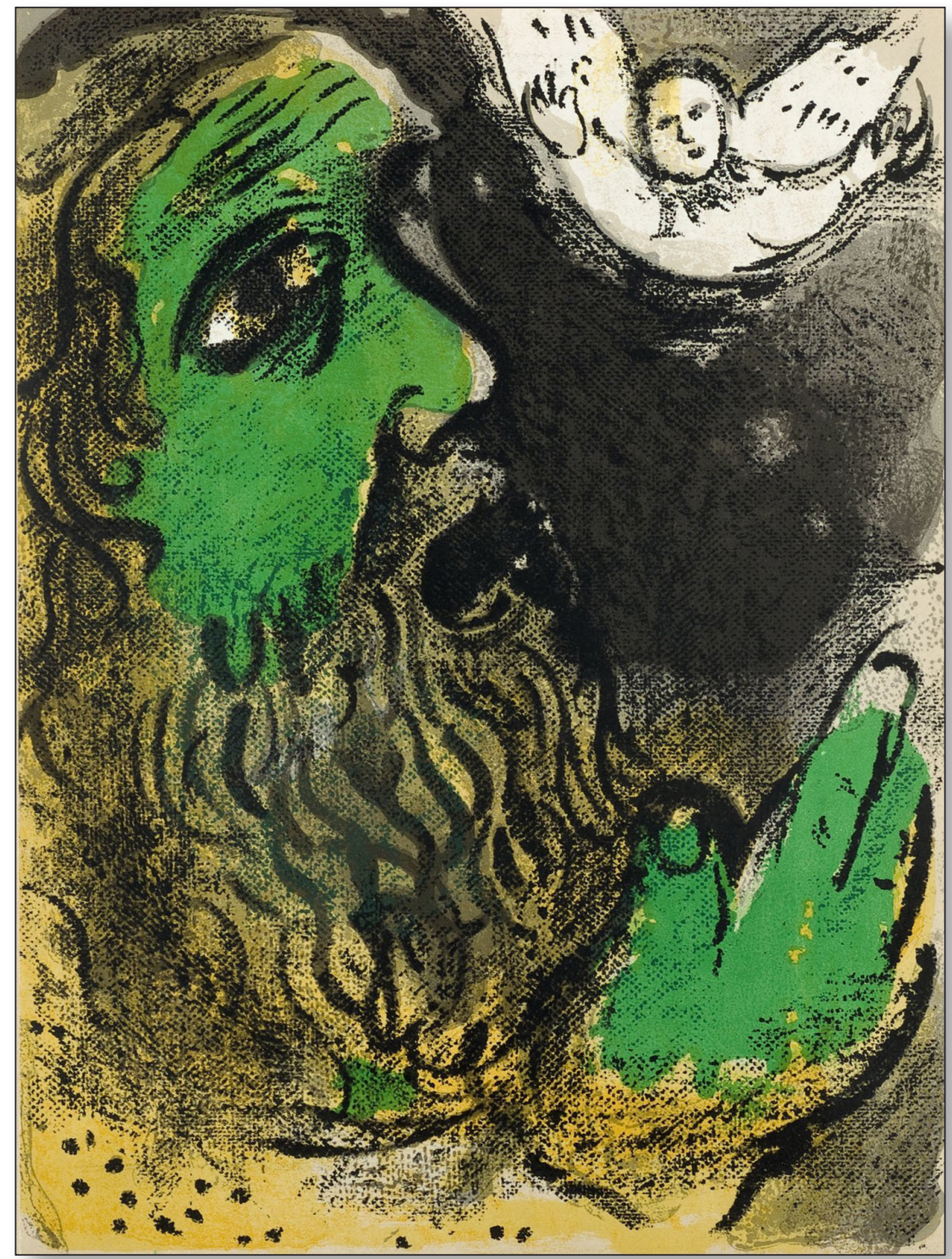

Fig. 3. Marc Chagall. La oración de Job, Litografía, Verve art magazine, 1960.

\section{JOB CRITICA LA SABIDURÍA TRADICIONAL, PERO NO CONOCE OTRA}

El libro de Job se sitúa en el interior de un proceso reflexivo dentro de la pedagogía progresiva bíblica. En ese progreso, el primer peldaño lo constituye el libro de los Proverbios. Este libro sintetiza y asimila cómo fue recibida en Israel la sabiduría antigua de las potencias internacionales del entorno bíblico. En esa recepción lo más destacable fue la integración de su fe monoteísta en la reflexión sapiencial y su popularización. La sabiduría en Israel no se 
dedicó en exclusiva a unas élites políticas o administrativas como en Egipto o Mesopotamia. $\mathrm{Y}$ al ser algo popular y general, que intenta preparar para la vida de toda la comunidad, se encontró con sus propios límites. Esa sabiduría tendía a un cierto automatismo: quien obraba bien recibiría bienes y quien se comportaba en contra del orden establecido, recibiría males. Eso implicaba una dinámica del do ut des. Además, toda esta reflexión se hacía sin conocer el destino del hombre después de la muerte. Las ideas sobre la resurrección y la pervivencia del alma después de la muerte no se irán consolidando en Israel hasta el s. II a.C. Por ese motivo, el espacio donde se plantean los problemas existenciales humanos en el libro hebreo de Job, no dispone en absoluto de una solución «ultramundana». Todo debe resolverse en el «aquí».

Teniendo en cuenta este diálogo de la sabiduría de Israel con la sabiduría «internacional», no resulta extraño que todos los personajes del libro sean no-judíos. Ni Job, ni su familia, ni sus amigos son judíos. El ambiente temporal y espaciales del relato es el período patriarcal de inicios del segundo milenio. Salvo Elihú, que sí es un nombre judío, las referencias del libro apuntan a la región edomita en la frontera con Arabia. Sin embrago, el libro es profundamente judío. Su teología, su lenguaje, su simbología y el uso de otros textos concretos de otras secciones de la literatura bíblica, lo sitúan sin duda en un contexto judío. No debe extrañar nada esto, habida cuenta de que es un fenómeno frecuente en la literatura sapiencial bíblica. El propio libro de los Proverbios contiene secciones de dichos sapienciales atribuidos a sabios extranjeros. ${ }^{4}$ Incluso contiene una traducción adaptada de una obra egipcia anterior. ${ }^{5}$ Para los hagiógrafos hebreos no parece haber conflicto entre fe y razón. Si había algo valioso en la sabiduría de los pueblos vecinos, por ser percibida como verdadera a través de la razón, se tenía como enseñanza válida porque formaba parte del orden que el Creador había inscrito en el cosmos.

Pero esa sabiduría no daba razón de toda la experiencia humana. Por eso, esa sabiduría entró en crisis en los libros de Job y Eclesiastés (Qohélet) y sufrió una severa crítica. Al final todo acaba bien en la síntesis integradora del Eclesiástico (s. II a.C.) y del Libro de la Sabiduría (s. I a.C.). En estas dos obras se avanza en una comprensión de la retribución en el más allá que aporta otra solución al problema.

La amplia sección poética que contiene los diálogos de Job con sus amigos y sus largos monólogos están llenos del debate entre la posición sapiencial tradicional y su aparente fallo en la vida de Job. Sus amigos, que le acompañan en su sufrimiento, hacen uso del esquema convencional e intentan ayudarle. Si ha sufrido un castigo es porque es culpable de algo. Cuanto antes lo reconozca y haga penitencia, antes podrá disfrutar del favor divino. Sin embargo, Job y el lector saben que no es culpable. El motivo de su sufrimiento es que Dios permite la prueba del «tentador» para demostrar que tiene razón y que Job es justo no por su interés, sino de verdad, sinceramente. El lector sabe también que la prueba es temporal y que acabará en una bendición mayor a la inicial. Eso hace que pueda leer con paz las palabras subversivas, sazonadas de un atrevimiento cercano a la blasfemia, que Job dirige a un Dios que sigue en silencio ante su desafío desabrido. Job nunca acaba de romper con Dios. Realmente no blasfema, aunque habla con crudeza (cf. Job 19) y muestra su dolor ante el silencio

4. Algunas de sus secciones están atribuidas a sabios extranjeros sin dar su nombre, pero en las secciones finales del libro se citan a Agur y Lemuel. Ambos se ubican en una región cercana a la de Job, de hecho, es una idea común en el mundo bíblico considerar la región de Arabia confinante con Palestina como una zona típica de sabios. 5. Instrucciones de Amenemope (s. XII a.C.). 
de Dios. Realmente, sus palabras son una queja y una súplica simultáneas. ${ }^{6}$ He aquí al Job poético, lleno de dolor, dudas y desesperanza, que habla de Dios en los siguientes términos:

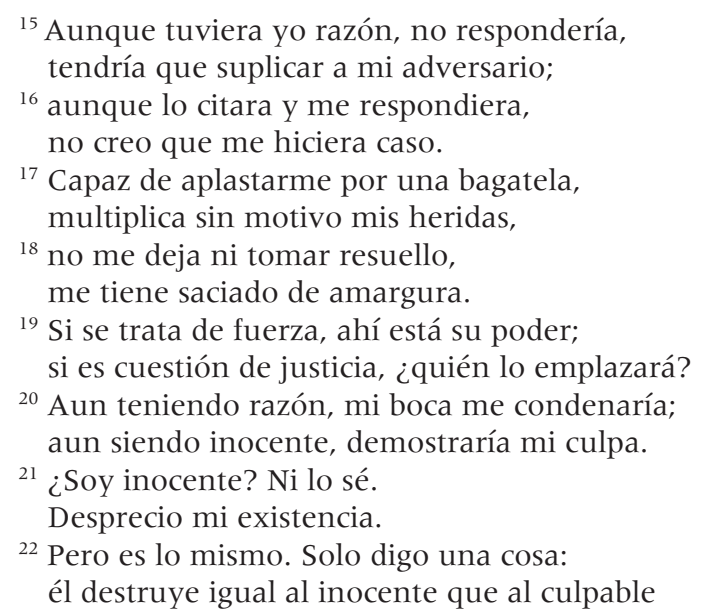

(Job 9, 15-22)

En contraste, el Job narrativo es un personaje casi mudo. Lo poco que dice es ejemplo de «resistencia» y de confiado abandono en Dios. Así contesta a su mujer cuando ésta lo anima a rechazar a Dios: «Hablas como una necia. Si aceptamos de Dios los bienes, ¿no vamos a aceptar los males?» (Job 2,10). Sin embargo, el Job poético critica la bondad divina y su justicia porque la vida que Dios da al hombre es efímera, dolorosa, desesperada y abocada al Sheol. ${ }^{7}$ Dios parece perseguir de modo despiadado al hombre y no comparte con el hombre sus razones o motivos. Por eso, el hombre se siente esclavo y traicionado y acaba por pedirle cuentas. En ese sentido el libro de Job admite dos comprensiones. Por un lado, Satán y sus abogados, los amigos de Job, le someten a un juicio para determinar su culpabilidad y así poder demostrar que la sabiduría tradicional tenía razón. Pero como Job es justo y defiende con vehemencia este punto, al final, el libro parece llevar a juicio al mismo Dios.

La inocencia de Job es otro elemento estructural importante de la obra. Como cualquier lector podrá suponer, este punto es una verdadera exageración. No existe ningún ser humano que pueda defender con verdad su inocencia en todos los puntos en los que es examinado Job por sus amigos, y por él mismo. Este punto será usado en la interpretación cristiana posterior al aplicar las palabras de Job al mismo Jesucristo, el verdadero inocente.

La amplia sección poética donde cada personaje despliega toda su capacidad retórica para defender su visión del mundo se intensifica con el alegato final de Job (capítulos 29 a 31). Además, el compositor incluyó una pieza independiente (el poema de la Sabiduría inalcanzable del capítulo 28) como adelanto de la solución que vendrá en la sección final en la que Dios por fin interviene. En efecto, toda esta tensión mantenida durante tantas

6. Como contrapeso a la paciencia y resistencia de Job en medio de su sufrimiento, aparece la reacción desabrida de su mujer, que parece formar parte del equipo del «tentador» cuando le dice: "¿Todavía persistes en tu honradez? Maldice a Dios y muérete» (Job 2,9).

7. Este término indica el mundo subterráneo de los muertos donde justos e injustos conviven en una existencia sombría imposible de describir. Con la llegada de la apocalíptica esta imagen se enriquecerá. Con la distinción de alma y cuerpo fruto del contacto con el helenismo, sin dejar del todo una visión unitaria del hombre, el Sheol o Hades será el lugar de espera del juicio y la resurrección. En él, los justos y los pecadores ocupan espacios diversos. 
páginas desembocará en las teofanías que describen la grandiosidad del cosmos y sus misterios (Job 38,1-42,6). Dios mismo irrumpirá en la escena, pero antes, el compositor final retrasa ese momento climático un poco más con la intervención de un cuarto amigo (Elihú).

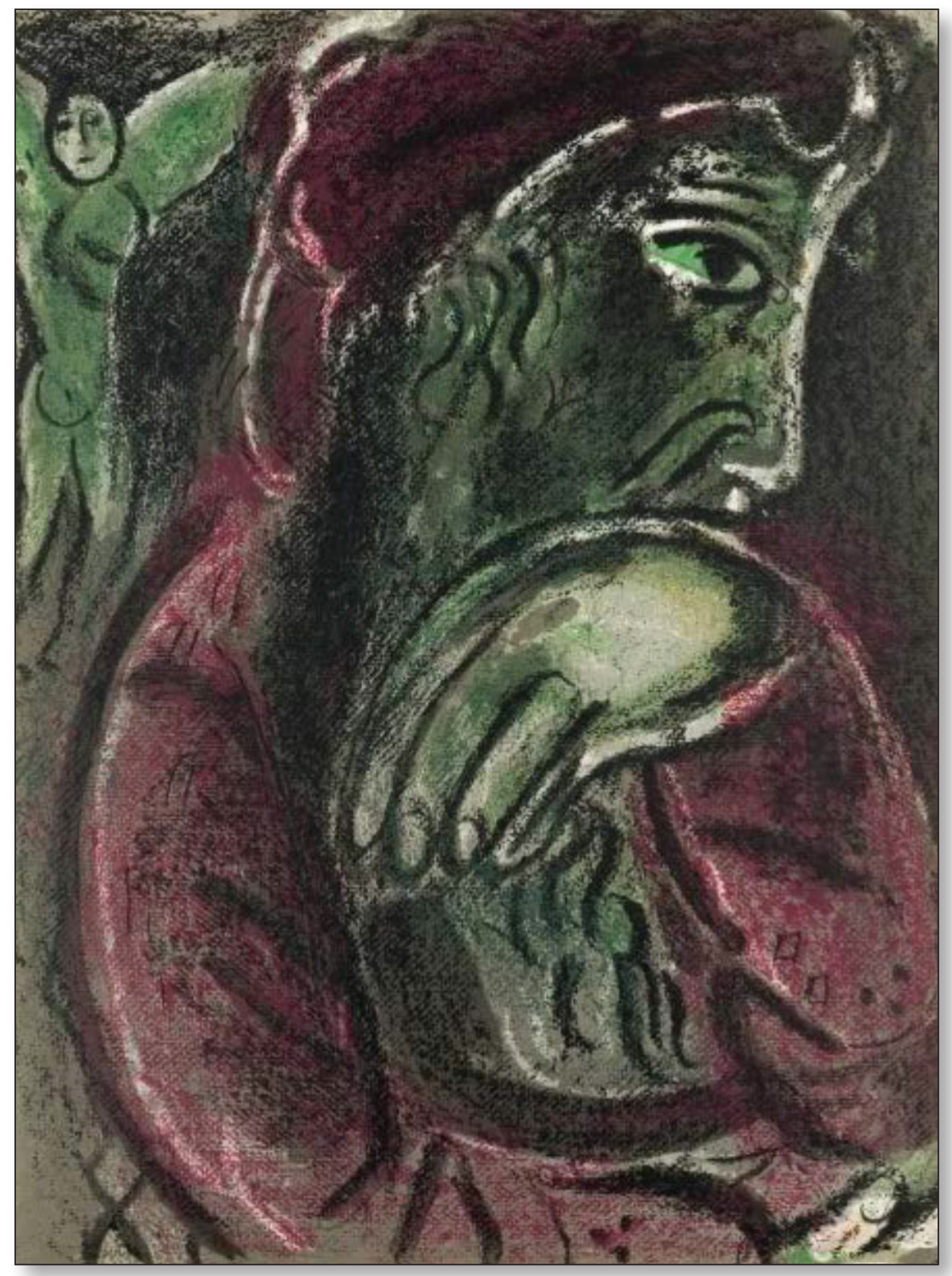

Fig. 4. Marc Chagall. La desesperación de Job, Litografía, Verve art magazine, 1960.

Pero antes de detenernos en las novedades del libro, que ofrecen alguna respuesta al enigma planteado, podemos acudir a la síntesis que Gerhard von Rad, buen conocedor de la sabiduría bíblica, nos ofrece sobre la mente y los sentimientos del Job poético:

IMAGO, NÚM. I I, 2019, 21-40 
La crisis lacerante que experimenta la fe de Job sólo se puede explicar por el hecho de que el personaje vive, piensa y se debate en un amplio contexto de viejas tradiciones de la fe yahvista. Se podría incluso preguntar si la vinculación con estas tradiciones tan inveteradas no era, en realidad, mucho más rigurosa en la situación de Job que en el caso de sus amigos. El grito anticonformista de Job salta desde ese Dios terrorífico de su experiencia al Dios que desde siempre se ha manifestado como el salvador de los marginados y de los débiles, el defensor de los desvalidos. Job sólo podrá vivir y respirar si ese Dios se declara decididamente a favor suyo (Rad, 1985: 280).

Para el lector atento, la tensión que produce la obra tiene que ver también con la descripción que Job hace con nostalgia del Dios de su fe. Un Dios que parece ahora ausente, pero un Dios que no se corresponde con su experiencia presente.

\section{LAS NOVEDADES IMPLÍCITAS QUE EL LIBRO APORTA}

Job critica la sabiduría tradicional, pero no se sale de ella y dice a sus amigos: «Explicadme las cosas y callaré, aclaradme en qué me he equivocado; los argumentos ajustados persuaden, pero ¿qué demuestran vuestras razones?» (Job 6,24-25). Job también usa la ecuación "culpa = castigo" y acepta que es válida. En cierto modo, su imagen de Dios coincide con la de sus amigos, pero su experiencia le sitúa en un campo inexplorado todavía. Lo que repite una y otra vez es que él está experimentando un fallo en esa ley y no entiende la razón. Por lo dicho anteriormente, el lector sabe que el sufrimiento no siempre es un castigo, sino que puede ser un modo de probar la rectitud del que se dice justo. Y esto es una novedad que Job desconoce. Es una de las novedades que la Biblia ofrece a través de este libro. Además, Elihú, el amigo de nombre judío, añade otra joya al conjunto: «[Dios s]alva al desdichado por medio de su desdicha y le abre el oído por medio de la desgracia» (Job 36,5-23). Según este personaje, y antes de que Dios aparezca y dé su respuesta, el dolor es «maestro». El sufrimiento es un estado en el que el hombre se sitúa en un ángulo de visión tal, que le permite reconocer su verdadera posición en el mundo: él no es Dios, ni el Dios real es el que "cabe» en su cabeza. La realidad nos excede, y sólo quien aprende a superar esa medida, podrá ser sabio de verdad. Antes, en los diálogos con los amigos ya había aparecido la idea del dolor como medio de corrección, pero es ahora con Elihú cuando este argumento emerge con toda claridad.

En la literatura profética, especialmente en el segundo Isaías, aparecerá la idea del sufrimiento con sentido redentor: el justo que se ofrece por el pueblo. Y para captar toda la profundidad de este planteamiento, habrá que esperar más hasta llegar a la comprensión cristiana del sentido de los sufrimientos redentores de Jesucristo. Ahora, en el momento del libro de Job, estamos en un punto previo en todo ese proceso.

Lo que hace Elihú es criticar el "automatismo" de la sabiduría tradicional, encarnada en los argumentos de Job y de sus amigos. Él muestra una sabiduría más sofisticada que defiende una visión sobre Dios más perfecta. De esa manera el compositor del libro defiende la superioridad de la sabiduría judía. Ésta incluye la tradicional, pero, como conoce al Dios único y verdadero, puede ofrecer mejores respuestas. ¿De qué manera el dolor hace de maestro? La respuesta divina final se engarza perfectamente con la aportación de Elihú. Cuando Dios aparece, no responde a las preguntas acuciantes de Job. Dios habla de otras cosas, y deja de estar en el banquillo de los acusados y empieza Él a someter a preguntas a Job. 
${ }^{1}$ El Señor habló a Job desde la tormenta:

2 "¿Quién es ese que enturbia mis designios sin saber siquiera de qué habla?

${ }^{3}$ Si eres hombre, cíñete los lomos; voy a interrogarte y tú me instruirás.

${ }^{4}$ ¿Dónde estabas cuando cimenté la tierra? Cuéntamelo, si tanto sabes.

${ }^{5}$ ¿Quién señaló sus dimensiones (¡seguro que lo sabes!) o le aplicó la cinta de medir?

${ }^{6}$ ¿Dónde encaja su basamento o quién asentó su piedra angular

${ }^{7}$ entre la aclamación unánime de los astros de la mañana y los vítores de los hijos de Dios?

8 ¿Quién cerró el mar con una puerta, cuando escapaba impetuoso de su seno,

${ }^{9}$ cuando le puse nubes por mantillas y nubes tormentosas por pañales,

${ }^{10}$ cuando le establecí un límite poniendo puertas y cerrojos,

${ }^{11}$ y le dije: "Hasta aquí llegarás y no pasarás; aquí se romperá la arrogancia de tus olas"?

(Job 38,1-11)

En las dos teofanías Dios describe la grandeza de la creación tal como era concebida en el mundo semita antiguo. Ante esa grandiosidad llena de misterios Dios pregunta a Job si los conoce. Y si no es capaz de conocer la grandeza de la creación, su belleza y orden, ¿no son sus palabras anteriores un poco torpes y pretenciosas? Dios sabe lo que hace y el saber de Job es limitado. Sólo le queda un camino: confiar, vivir en el «temor» de Dios. Es desde la humildad que facilitad el sufrimiento desde donde el hombre puede contemplar la creación, y, a través de ella, vislumbrar los designios misteriosos del Creador. Su vida forma parte de algo enorme que no puede comprender en toda su envergadura. Pero de una cosa debe estar seguro: si Dios está pendiente de cada pequeño detalle del cosmos, lo está también de la suerte de los hombres.

De todos modos, Dios no da una explicación clara. Como sintetiza von Rad:

Dios renuncia a dar cualquier clase de explicación sobre sus «designios» para evitar confusiones. Prefiere pasar a la ofensiva con una serie interminable de preguntas sobre la creación y sobre el orden y desarrollo del universo. Por lo tanto, no se trata de divagaciones teóricas ni de principios genéricos de la actuación divina, sino de realidades fácticas y cotidianas. Esto quiere decir que la creación se abre como altavoz del testimonio que Dios da de sí mismo (Rad, 1985: 284).

Después de esta experiencia Job reconoce que ha hablado insensatamente. Antes pensaba que conocía a Dios, pero eso era falso. Se había hecho una imagen falsa del Dios verdadero. Todo sigue igual, pero su mirada ha cambiado. Es cierto que no había cometido ningún pecado que explicase su castigo. Es cierto que Dios había permitido la prueba de su sinceridad. Es cierto que Job sufre y que se queja y que suplica; y es cierto que en el dolor el Dios verdadero se muestra y le corrige del único pecado que Job había cometido: el orgullo de querer comprender algo que le excede. Ha querido ser como Dios, se ha acercado 
demasiado al árbol prohibido. Ha querido entender un libro complejo leyendo sólo una página elegida al azar. Cuando Job deja de buscar a un culpable de sus males, se da cuenta de la desproporción entre él y Dios.

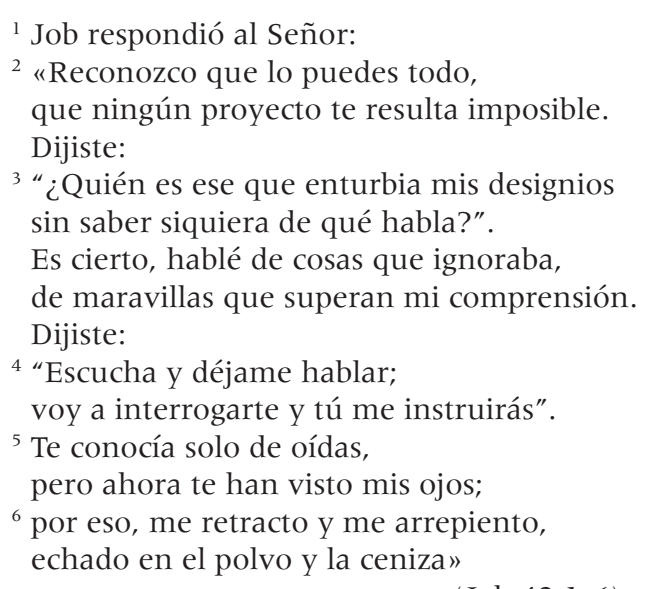

(Job 42,1-6).

La parte final del libro (narrativa de nuevo) muestra a un Job que intercede por sus amigos, que recibe la ayuda de unos familiares, y que, con la bendición divina, consigue recuperar y aún aumentar su familia y sus riquezas. Como todo cuento, la cosa acaba muy bien.

\section{LA PRIMERA INTERPRETACIÓN DEL LIBRO DE JOB}

\section{CUESTIONES PRELIMINARES}

Hasta ahora hemos analizado la versión hebrea del libro de Job porque es considerada la más antigua de todas las conservadas. Lo hemos hecho con la comprensión contemporánea que lo analiza descubriendo su profunda significación a través del análisis de la estructura de la obra y de las funciones de los diversos enunciados implicados, que, a modo de "componentes», acaban en una "resultante» final. Sin embargo, si recorremos el camino de la interpretación y transmisión de este libro bíblico, encontramos que nuestro análisis contemporáneo no coincide con el modo desarrollado en las diversas etapas y comunidades. Eso es así porque en aquellos momentos primaban otras necesidades. De lo que no podemos dudar es de la canonicidad del libro de Job. Este libro formó parte del canon de Escrituras de todos los grupos implicados: nunca se ha dudado de su canonicidad, aun siendo interpretado de modos diversos.

\section{EL JUDAÍSMO PRE-RABÍNICO Y CRISTIANISMO}

Cuando el Mediterráneo oriental fue helenizado, el judaísmo entró en diálogo profundo con él. No se podrá nunca magnificar bastante el hecho trascendental del fenómeno de «transculturación» que supuso la traducción de las Escrituras de Israel al griego. Además, 
este proceso fue simultáneo a la eclosión del movimiento apocalíptico y al gran prestigio y desarrollo cultual del mundo judío, centrado en Jerusalén. La confección de las Escrituras judías en griego no fue una simple traducción. Se trató de una interpretación actualizadora dentro de una identidad en progreso. Además, cada vez se fue haciendo más claro el destino del hombre a partir de la muerte. Por eso, no resulta extraño que el libro de Job según su versión griega (LXX) suavice mucho al tenso Job poético. Veamos un ejemplo. La versión hebrea de Job 14,14 dice: "Si un hombre muere, ¿vivirá otra ves?». Sin embrago, de esa duda llena de ironía del Job hebreo, pasamos a una fe llena de seguridad expresada en griego que dice: «Si un hombre muere, ¡vivirá otra vez!». Son innumerables los ejemplos similares a este que se podrían aducir aquí. En líneas generales podemos afirmar que el Job poético, poco piadoso en la versión hebrea, se acerca al Job popular narrativo, y de esa manera se evitaba a los lectores los largos pasajes de difícil comprensión. Como resultado, Job aparece como un ejemplo de virtud, pero la fuerza expresiva de la obra hebrea se diluyó un tanto. Otro factor decisivo en la versión de los LXX del libro de Job es que se le sitúa explícitamente en la parentela de Abraham, haciéndolo más cercano al pueblo elegido y a su Alianza.

«La traducción griega del libro de Job presenta notables diferencias respecto al hebreo. Es en torno a una sexta parte más corto que el masorético, siendo el texto griego el que se leyó hasta el año 250 aproximadamente» (Fernández y Spottorno, 2013: 416). En ese tiempo, Orígenes popularizó una versión que devolvía el sexto perdido desde la recensión judía de los LXX hecha por Teodoción en el s. II d.C. En cualquier caso, la versión griega fue muy común en el judaísmo del cambio de Era y constituyó el Antiguo Testamento de los primeros cristianos. Este fenómeno de transculturación supuso una adaptación del libro y de su mensaje. El Job poético aparecía ahora suavizado quizás por la nueva fe en la vida después de la muerte y en la esperanza de la resurrección. En una expansión del final del libro el traductor añade al texto hebreo: «Y ha sido escrito acerca él (Job) que resucitará con aquellos a quienes Dios resucite» (Job 42,17 [LXX]).

Posiblemente, en mayor medida que lo anterior, el factor clave para comprender la idea que el judaísmo cercano al cambio de Era tenía de Job se debe a una obra apócrifa denominada Testamento de Job. Este libro, muy influido por los LXX, fue escrito también en Egipto, entre el s. I a.C. y el I d.C. En este libro, Job aparece en paralelo con Abraham. También él abandona la idolatría siendo aún joven y descubre al Dios único y verdadero. El relato cuanta cómo su lucha es contra Satán (ahora sí nombre propio de un personaje enemigo de Dios). Job jamás lucha contra Dios ahora. Los esfuerzos de Job se dirigen a destruir los ídolos paganos y sus templos. Por ese motivo se hace merecedor de la ira satánica. Además, dentro de sus males, Job siempre aparece como modelo de fe porque confía en su futura resurrección.

El autor de este breve escrito nos presenta [...] un Job distinto del de la Biblia hebrea. Es un personaje que encaja mucho mejor en las descripciones del homo religiosus de las sectas pietistas que en el molde del Job canónico.

El Job del Testamento es un pagano virtuoso, ansioso de encontrar al Dios verdadero $(2,4)$, y que, cuando lo halla, rompe radicalmente con el culto pagano. Lo mismo que Abrahán, Job es un prosélito auténtico. Rodeado de sufrimientos, consecuencia de su adscripción a la religión verdadera, no cede ante la tentación. A diferencia del Job canónico, el del Testamento es un modelo de sumisión a la voluntad divina. Sus virtudes características [...] son la paciencia-resistencia [...] y la liberalidad caridad [...]. (PIÑERO, 1987: 166-167). ${ }^{8}$

8. Cf. también Crenshaw, 2011: 25-29.

IMAGO, NÚM. I I, 2019, 2I-40 
Este Job lleno de virtud, lleno de confianza en Dios y que resiste todo mal, será el campeón exaltado también en los escritos cristianos de este período. En la carta de Santiago se recoge: "Hermanos, tomad como modelo de resistencia y de paciencia a los profetas que hablaron en nombre del Señor; mirad: nosotros proclamamos dichosos a los que tuvieron paciencia. Habéis oído hablar de la paciencia de Job y ya sabéis el final que le concedió el Señor, porque el Señor es compasivo y misericordioso» (St 5,10-11). En esta perspectiva, Job es un ejemplo de santidad. Además, como Job no es un judío, esto ayuda para argumentar bíblicamente la llamada a los gentiles en la polémica antijudaizante de los orígenes del cristianismo. En efecto, Job es santo y no estaba bajo la Ley pues es anterior a Moisés. Esta es la imagen de Job que pasará a los Padres de la Iglesia y que será muy comentada por alguno de ellos.

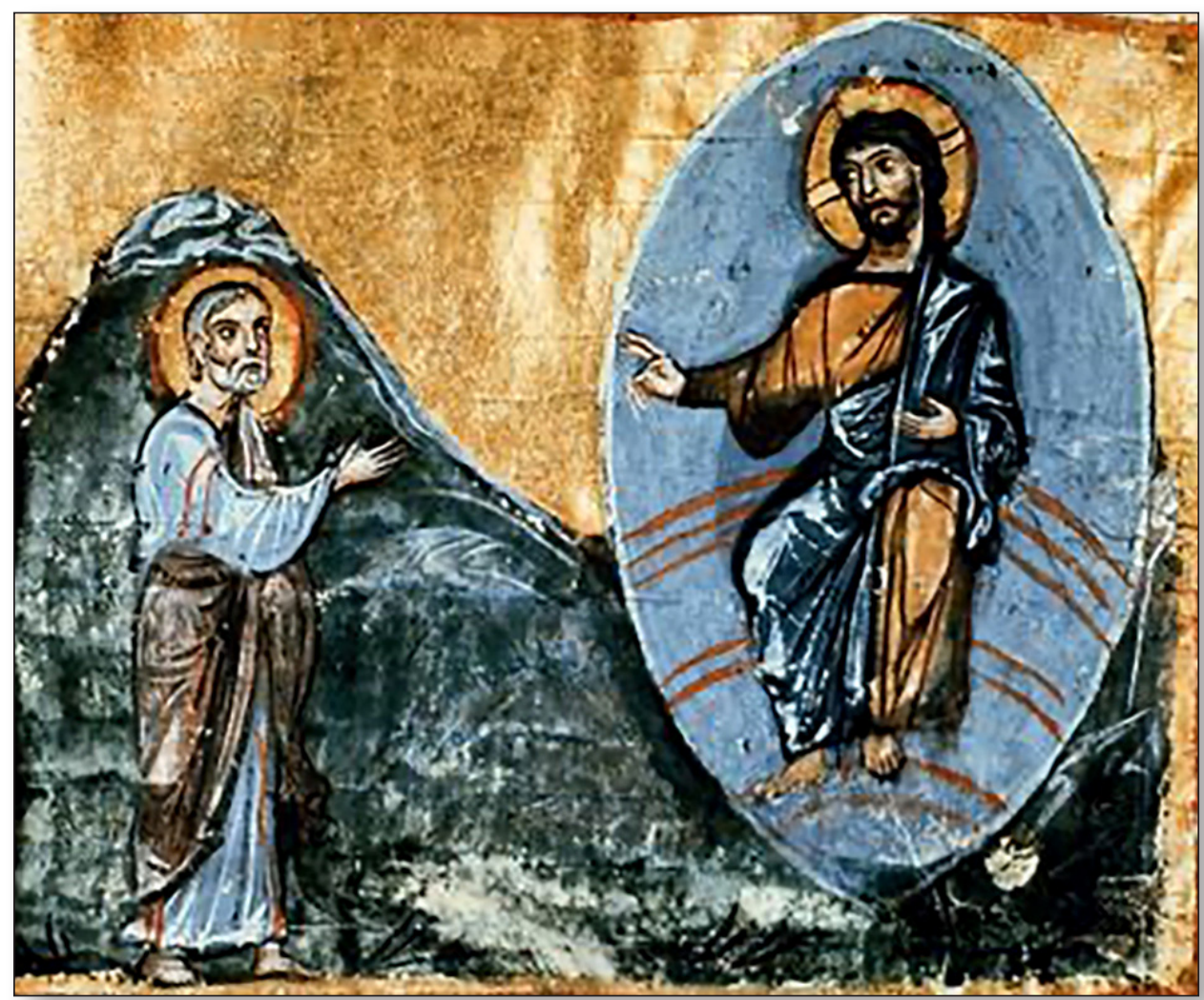

Fig. 5. Job conversa con Dios, miniatura del Libro de Job, códice B. 100 del monasterio Megisti Lavra, Monte Athos.

\section{EL JUDAÍSMO RABÍNICO}

El factor clave para la concepción del Job cristiano es, sin duda, el paralelismo que los cristianos establecieron entre Job y Jesucristo. Éste último sí que podía proclamar con verdad su inocencia. Las palabras de Job, puestas en labios de Cristo no sonaban blasfemas, parecían adquirir un sentido más profundo y profético. Job se veía entonces como un anuncio profético de la pasión. 
En paralelo con el desarrollo cristiano, el judaísmo tuvo que reformularse, en especial, después de las dos guerras acaecidas en Palestina contra los romanos. En ese proceso, los rabinos volvieron a su lengua original y comenzaron a revisar el texto hebreo. En el período tannaítico (ss. I-II d.C.) los rabinos se dividen. Unos toman partido por el Job narrativo y piadoso y otros se fijan en el poético y arrogante. En el ideario rabínico, existía, por supuesto, la idea de que todo ser humano posee un valor incalculable y es potencialmente justo. La lectura exegética de las genealogías contenidas en el Génesis hablaba de que todos los seres humanos provenían de Dios. Todos fueron creados por Él a su imagen. En esos escritos rabínicos, a Job se le pone entre los siete profetas no judíos. Pero esa concepción inicial no se va a mantener. De esa visión común con los cristianos se pasó a una cierta duda sobre la santidad de Job. Para algunos rabinos, Job no fue tan justo. Su confianza en Dios se debía al miedo y no al amor, como Abraham. Al leer el texto hebreo los rabinos descubren a un Job poético que no tiene fe y dice cosas muy duras. Así, se le empieza a poner después de los judíos y de los prosélitos. A Job se le hace culpable de irreverencia y se explica el final feliz del libro en atención a los méritos que se describen en su inicio narrativo. Para muchos rabinos, es como si Dios, al final, no tuviese en cuenta todo lo que dice Job en su sección poética. A continuación, resumimos algunas de las relecturas sobre Job realizadas por los rabinos. Puede resultar sorprendente que se sucedan interpretaciones tan diversas sobre lo mismo. Eso es debido a nuestros moldes culturales, diversos de la mentalidad judía mucho más flexible en la interpretación. ${ }^{9}$

La cosa se agrava porque en muchos comentarios posteriores a la Torah, Job viene identificado como alguno de los personajes extranjeros que tomó partido en contra del Pueblo elegido. En ocasiones se lo sitúa en tiempos de Moisés, como uno de los consejeros del Faraón. En esas ampliaciones "midráshicas», Job aparece haciendo daño a los hebreos como parte del aparato del Faraón. Como respuesta, Dios envía a Satán para que lo castigase. De ese modo, al estar ocupado el «Tentador» haciendo sufrir a Job, el Pueblo pudo huir cruzando el Mar Rojo. En esta nueva narración se explica la acción de Dios sobre Job. Job no es justo y merece un castigo. Además, esa circunstancia forma parte de la historia del Éxodo y explica que el Pueblo pudiese escapar de las manos del Faraón. Este conjunto de interpretaciones tiene en cuanta al Job poético, pero lo dejan en un segundo lugar porque sus sufrimientos están justificados por sus acciones contra los hebreos.

En una línea diversa, existía otra forma de oponerse a los argumentos cristianos. Frente al uso que hacían los cristianos del «santo extranjero" algunos rabinos cambiaron la interpretación de Job. Muchos empezaron a buscar argumentos para interpretar el texto inspirado de tal manera que se pudiese convertir a Job en un piadoso judío. Algunas tradiciones rabínicas tardías recogen unas narraciones en las que se aseguraba que Job había nacido circuncidado y sin culpa. Para algunos rabinos, en la historia anterior a Moisés habían existido personas que habían nacido circuncidadas por gracia especial de Dios. De esa manera cumplían con la Ley. Además, hay que recordar que, para el judaísmo de esa época, la Torah era uno de los diez objetos celestes que Dios creó antes del Mundo. Es decir, que el argumento cristiano que veía imposible de cumplir la Ley antes de que Dios se la diese a Moisés no es válido. En esta exaltación de Job, el Job poético parece desaparecer de la escena y volvemos a una imagen idealizada de un santo, modelo de todo prosélito.

9. Para una visión de conjunto de este corpus complejo de literatura rabínica, puede consultarse: Ginzberg, 2003: 451-463.

IMAGO, NÚM. II, 2019, 2I-40 
En una línea totalmente diversa, para algunos rabinos, Job era unos de los judíos que retornaron después del destierro de Babilonia. De ese modo se establece una identificación entre este personaje bíblico y la existencia como judío errante, vagabundo y perseguido que caracterizaba la época posterior a la expulsión de Palestina en el s. II d.C. en tiempos de Adriano. Aquellos judíos que habían perdido hijos, posesiones y habían sido expulsados de su tierra encuentran en Job un símbolo con quien identificarse. De esa manera se convierten en el Job poético en espera del desenlace final feliz del Job narrativo. Esa espera parece haber durado casi diecinueve siglos. En esta interpretación sí vuelve a tener peso específico el Job que clama con virulencia a Dios y el silencio divino es un modo de proyectar hacia un futuro lejano la solución definitiva a la diáspora del pueblo judío.

\section{PATRÍSTICA}

En los autores cristianos del período bizantino Job es un ejemplo de paciencia y hospitalidad. También es un precursor que anuncia los padecimientos de Cristo y sirve de modelo para la vida ascética de los ermitaños y monjes del desierto. Por último, algunos Padres ven a Job como un modelo de las posibilidades de la potencialidad humana. De hecho, si se lee despacio la parte narrativa del libro de Job, se ve que todas las riquezas que Job tiene al principio y al final de la historia no son fruto de un regalo divino. El texto dice que Dios bendecía a Job, pero era él, con su trabajo, el que hizo rendir todo aquello.

Por su influjo posterior, nos detenemos ahora en dos puntos concretos de este período. El primero es la interpretación de san Ambrosio de Milán. Ambrosio negaba que Job fuese tipo de Cristo. Para él, la lección importante del libro era que el sufrimiento es camino de salvación porque perder las riquezas de esta vida, el desprendimiento, y la ejercitación en la virtud de la fortaleza, hacen posible la vida espiritual. Ambrosio ve en Job a un campeón cristiano que asume las virtudes paganas. Siguiendo esta senda, quien soporte las tribulaciones corporales con dignidad podrá tener acceso a los bienes espirituales. Job es así el modelo del asceta cristiano. En esta línea será muy conocido y tendrá un gran influjo la obra Moralia in Job de Gregorio Magno.

El segundo punto interesante en este período es el uso que los pelagianos hicieron de esa imagen virtuosa de Job. Para ellos, esta visión ejemplar de Job les reafirmaba en su doctrina acerca de la salvación sin la gracia de Dios.

En otra línea y dentro del mismo período histórico y cultural, sólo Jerónimo parece darse cuenta de la distancia entre las dos voces presentes en el libro de Job. Y lo hace porque traduce la Escritura al latín acudiendo a los textos hebreos y teniendo en cuenta el parecer de los rabinos. Sin embargo, por el uso eclesial, en su traducción se conservan muchos elementos propios de los LXX y que hacen menos clara esa distancia entre los dos Jobs. ${ }^{10}$ En sus comentarios no se destaca la distancia entre esas dos enunciaciones, entre esos dos puntos de vista distintos. Y esto sucede, lo repetimos ahora, porque el texto que usan estos autores es, sobre todo, los LXX y esta versión ha rebajado mucho la tensión entre esas dos visiones del mundo. Otro factor que relaja la tensión es que los Padres de la Iglesia realizaban una lectura canónica de la Escritura. Al leer y comentar el libro de Job, tenían en su mente toda la Escritura, incluyendo el Nuevo Testamento y el conjunto de realidades definitivamente reveladas en Cristo.

10. Las interpretaciones que los Padres de la Iglesia hicieron al hilo del comentario del libro de Job son abundantes. No disponemos de espacio aquí para detenernos en este particular. Para una introducción, puede consultarse Merino, 2010 


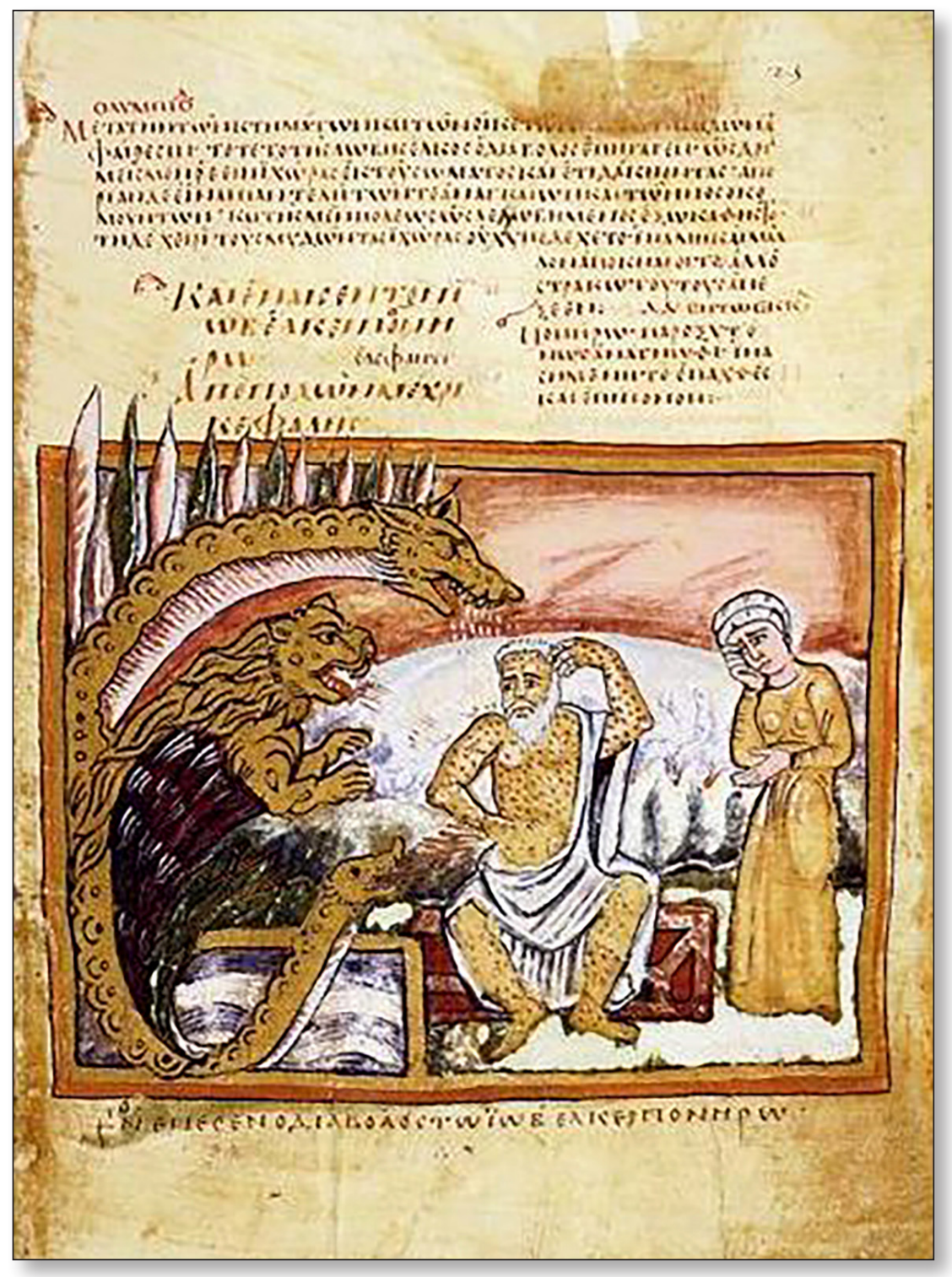

Fig. 6. Miniatura del Libro de Job, Manuscrito Vaticano 749, fol 25.

\section{EDAD MEDIA Y MODERNA}

En la Edad Media, en pleno aristotelismo, Maimónides centrará su atención en Job. Desde su concepción filosófica, Maimónides intenta dar coherencia al libro y quiere explicar la diferencia entre la virtud moral del Job inicial y su percepción intelectual al final del libro. Este filósofo ataca la interpretación rabínica tardía, carente de racionabilidad, y explica el sufrimiento de Job como el proceso necesario en el hombre para pasar de la virtud a un refinamiento intelectual que le permita "concebir» y contemplar a Dios, la verdadera recompensa. Podemos suponer en esta fecha que los diálogos con los judíos medievales y el

IMAGO, NÚM. I I, 2019, 2I-40 
avance en el uso de la filología semítica, propio de esta época y que eclosionará en el renacimiento, devolvió a la arena del debate intelectual la sección del Job sufriente en sus largos discursos poéticos.

En esa misma línea, Tomás de Aquino ve que Job tiene imperfecciones y que debe aprender a manejarse porque es torpe. Para Tomás, Job está bien instruido, pero es todavía un imprudente. Se parece a un estudiante que conoce la teoría, pero que aún no ha aprendido a manejarla bien en la vida. Job ni sabe expresarse bien ni acierta a comunicar la sabiduría que pose sólo en teoría. Además, para Tomás de Aquino, toda la polémica entre Job y sus amigos versa sobre la percepción del orden cósmico. Los amigos de Job afirman que la providencia divina actúa en la vida natural y en la humana. De ese modo estarían defendiendo un cierto determinismo divino en la vida de los hombres. Sin embargo, para Tomás, Job afirma la actuación divina en la naturaleza, pero defiende que en la vida del hombre existe la libertad. La última palabra de la justicia divina sólo puede darse en el fin de la historia cuando la libertad del hombre ya no pueda seguir actuando. Al final de la vida y de la historia Dios juzgará y se manifestará su justicia y providencia definitiva. Mientras tanto, esa realidad es misteriosa y desconocida para el hombre.

Acabando nuestro recorrido histórico y teniendo en cuenta la referencia a los pelagianos realizada más arriba, Lutero veía en el libro un peligro de "autojustificación». De ahí su interpretación opuesta a la realizada por los pelagianos. Estos olvidaban al Job poético, dolorido y desafiante, pero Lutero no. Por ese motivo pone su esfuerzo en mostrar a Job en su doble condición: como un santo y como un pecador. Job representa la paradoja de la existencia humana. La clave del libro es, para Lutero, las propias palabras de Job según la Vulgata: "Yo temo todos mis trabajos» (Job 9,28 [Vg]). Job duda siempre de todos sus méritos y eso ayuda a Lutero a ver en el libro una salvación por pura gracia, ya que Job no merece nada: es un pecador que recibe la salvación al final de un modo totalmente gratuito.

En el mismo entorno cultural, pero con un planteamiento diverso, Calvino ve en Job a un hombre llamado a confiar en la acción providente divina en el mundo, aunque ésta no se comprenda.

\section{CONCLUSIONES}

Fruto del recorrido desarrollado se puede concluir que la complejidad del libro de Job no fue comprendida en su profundidad hasta que la obra fue sometida a un análisis adecuado durante los decenios que nos preceden fruto de la exégesis bíblica científica y de su enriquecimiento debido al surgimiento de la crítica literaria y del desarrollo de la hermenéutica. Durante muchos siglos, el libro de Job, tal como está en su versión hebrea y que nuestras traducciones actuales nos presentan, ha sido poco leído y conocido. Toda la compresión del libro a lo largo de la tradición que lo transmitía se hacía desde una óptica marcada necesariamente por algún presupuesto que surgía en el contexto vital del lector. Ese proceso, inevitable, se repite en nuestro presente. También ahora podemos leer el libro en nuestro contexto.

El dolor del inocente es una constante antropológica en cualquier punto de nuestra historia. Y es ahora cuando podemos leer este libro, donde un hombre sufre la injusticia y percibe el silencio de Dios. He aquí el reto que nosotros lanzamos al Dios de «antes» en el que ahora no parecemos poder confiar. El problema del dolor, máxime si se trata de algún 
inocente, es en la actualidad un lugar común para muchos que rechazan la fe en un Dios trascendente. Quizás eso sucede por el orgullo de querer ocupar su lugar.

En la concepción actual, el hombre mide la realidad por aquello que puede comprender. Todo lo que sale fuera de ese campo es falso o absurdo. Pero toda existencia humana se encuentra con la «inevitable» experiencia del dolor. Ese dolor se puede convertir en el grito de Dios al hombre, como decía C.S. Lewis: "Dios nos susurra en nuestros placeres, nos habla en nuestra conciencia, pero grita en nuestro dolor; el dolor es un megáfono para despertar a un mundo sordo» (Lewis, 2016: 57-58).

Este proceso no puede ser sino personal. Ahí tenemos una tarea «inevitable». Lo que sí podemos asegurar es que el tema está, con toda su crudeza, en el interior de la Biblia y que los textos fundantes de la cultura a la que pertenecemos aún, si no hemos dejado ya de pertenecer, sí tocan el asunto. El reto que el hombre contemporáneo lanza a la religión sobre el problema del mal tiene su espacio reflexivo. Quizás compense una lectura del libro de Job para darnos la oportunidad de decir: "ahora te he visto».

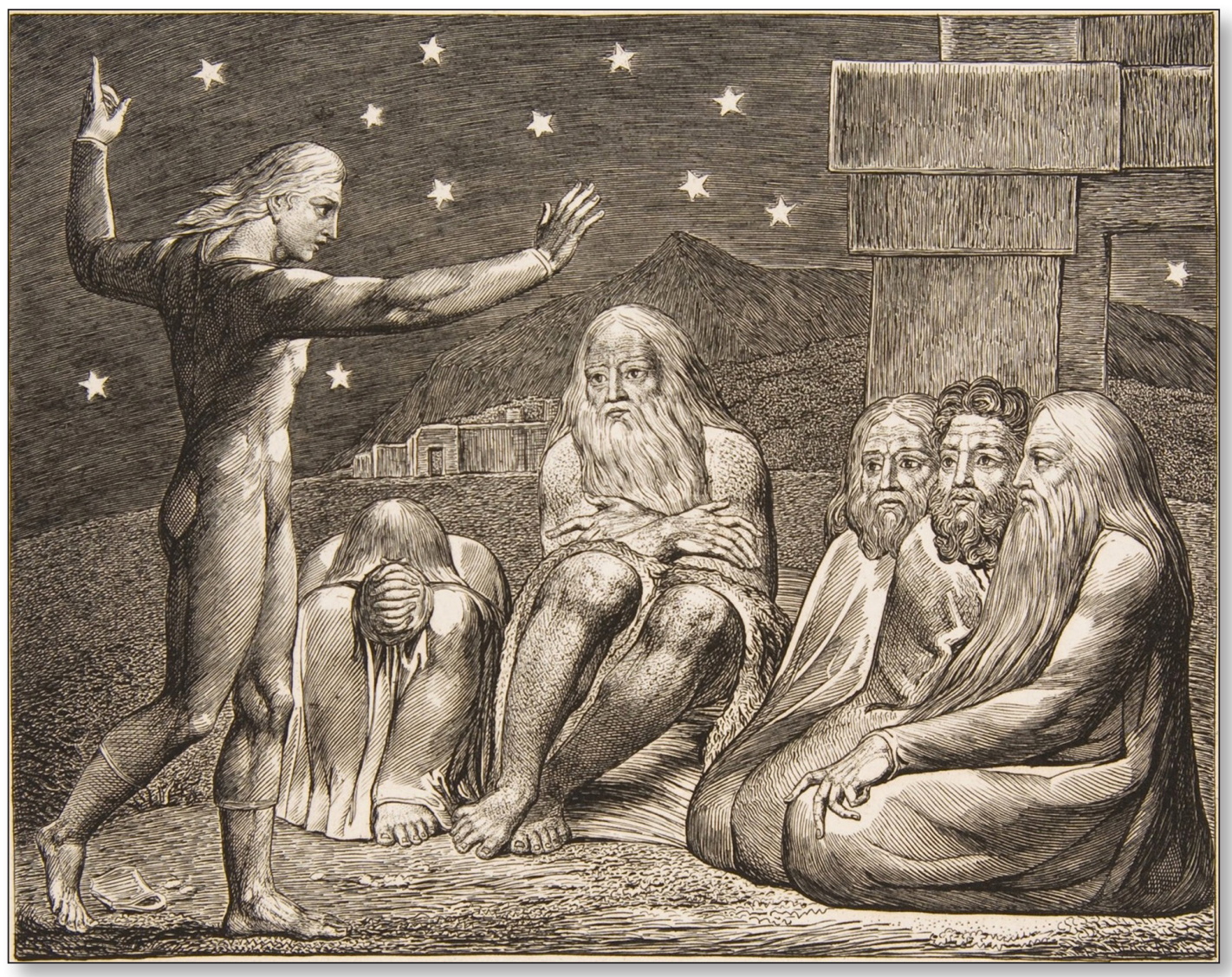

Fig. 7. William Blake, La ira de Elihu, uno de los grabados de la serie Illustrations of the Book of Job, Londres 1826. 


\section{BIBLIOGRAFÍA}

Allen, J. [2006]. «Job 3: Interpretation», en Longman III, T. - Enns, P. (eds.), Dictionary of the Old Testament: Wisdom, Poetry o Writings, Downers Grove, Illinois: Intervarsity Press, 361-71.

Alonso SchöKel, L. y Sicre Díaz, J.L. [1983]. Job, Nueva Biblia Española - Sapienciales 2, Madrid, Ediciones Cristiandad,).

Crenshaw, J.L., Reading Job: A Literary and Theological Commentary (Macon, GA: Smyth 8 Helwys, 2011).

Fernández Marcos, N y Spottorno Díaz-Caro, M.V. (Coords.), La Biblia griega Septuaginta III, Salamanca, Sígueme 2013, 413-424.

GinzberG, L. [2003]. Legends of the Jews, vol. I, Philadelphia: The Jewish Publication Society, $451-463$.

Hartley, J.E. [2006]. "Ancient Near Eastern Background», en Dictionary of the Old Testament: Wisdom, Poetry o Writings, Downers Grove, Illinois: Intervarsity Press, 346-346.

LÉVÊQue, J. [1987]. Job. El libro y su mensaje, Estella Verbo Divino.

Lewis, C.S., The Problem of Pain, (Québec: Samizdat University Press, 2016)

Merino Rodríguez, M. [2010]. Job. La Biblia Comentada por los Padres de la Iglesia y otros autores de la época patrística. Antiguo testamento, vol. 7, Madrid, Ciudad Nueva-

Morla, V., [2017]. Libro de Job. Recóndita Armonía, Estella, Verbo Divino.

Piñero A., [1987]. Testamento de Job, en Apócrifos del Antiguo Testamento, vol. V., Madrid, Ediciones Cristiandad, 166-167.

RaD, G von.[1985]. Sabiduría en Israel, Madrid, Ediciones Cristiandad, 261-286.

Trebolle, J. y Pottecher, S. [2012] Job, Madrid, Trotta.

Walton, J.H. [2006]. "Job 1: Book of», en en L Dictionary of the Old Testament: Wisdom, Poetry e Writings, Downers Grove, Illinois: Intervarsity, 333-346. 